\title{
LEGAL AND ECONOMIC PROBLEMS OF CIVILIAN SUPPLY
}

\author{
JOSEPH L. WEINER*
}

I

The impact of the war on the civilian economy of the United States is just beginning. Apart from automobiles and tires, large inventories have cushioned the blow of the inevitable shortages resulting from increased war production. From foreign experience, however, we know that goods available for civilian use will be greatly reduced-especially goods made from materials which are necessary for war production. Our own forecasts based on extensive economic data and our short experiences lead to the same conclusion. Careful allocation and rationing of the limited supply of goods is already necessary in some cases and will become increasingly prevalent. Curtailment of the comparatively unessential use of scarce materials will be imposed upon the civilian population. However, the supply of goods available for civilians cannot be reduced beyond a certain point without having adverse repercussions on war production itself. For the war effort itself is dependent upon civilians who sustain it. And the health and efficiency of these civilians depend in turn upon a basic supply of necessary civilian goods.

The civilian economy, of course, is not separate and independent. It is vitally integrated with our military economy. The war program is, after all, an over-all plan for making our total economy function efficiently during time of crisis. And although we refer to civilian supply and needs, it must be borne in mind that they overlap into military supply and needs.

The start of a great armament effort is bound to be confusing, especially when recovery from a previous depression has not been complete. Our so-called "defense" period was born under these circumstances. Germany, it is true, started arming in a period of depression; but because Hitler deliberately planned to put his country into war, he used all of Germany's unemployed resources to produce armaments and put a top on the civilian standard of living at the lowest level of the depression. In America, on the other hand, because we hoped that all-out war would not be necessary, we allowed our early military expenditures to have a "pump-priming" effect. Hence, during the first half of last year military and civilian production expanded side by side until unprecedented levels of civilian production were reached. Now,

*A.B., 1923, LL.B., I926, Columbia University. Member of the New York Bar. Deputy Director of the Division of Civilian Supply, War Production Board. Author of numerous articles in legal periodicals. 
however, we are in an all-out war. Actual and imminent shortages of vital raw materials mean that we must conserve these materials for military production. Productive facilities must be converted to necessary military production. Therefore, many of the industries which have been allowed to reach new highs of civilian production in recent months must be contracted even more rapidly than they expanded. It is inevitable that confusion should attend the rapid upswing and the even more rapid downswing of a sizeable portion of civilian production. Of course, if we had been able to continue to expand both our military and civilian production, the level of the civilian standard of living might have been maintained or not reduced as drastically. But now-we must place military needs first. Since our entry into war, expansion of necessary military production has consumed our total efforts.

As the raw materials and productive capacity of the country are appropriated for military production, an inevitable reduction of production of civilian goods must take place. For example, after military requirements for steel have been met, the reduced amount of available steel means that not all steel products being made today for civilian use can continue to be made. These shortages of raw materials and the increasing necessity for more military production facilities raise problems of allocation. Some end-products of steel are more essential to the civilian population than others. In fact, some steel end-products are absolutely essential to the civilian economy. Unless there is some type of planned allocation of the steel supply to the essential end-products, haphazard dissipation of our limited steel supply upon nonessential goods may occur. Allocation or rationing of these goods among the consumers, therefore, becomes necessary to ensure efficient prosecution of the war.

\section{II}

In general, allocation of resources is a continuing problem which must be met quite as much in peacetime as in wartime. We have this problem of allocationwhich is the basic economic problem-because we would all like to consume more goods and services than are available. Every economic system, therefore, faces and must solve, in some fashion or other, the problem of deciding which of the infinite variety of desirable goods and services we shall use our available land, labor, and capital to produce. In short, every economic system must solve the problem of allocating scarce factors of production between alternative uses.

Generally, in a system of free enterprise scarce resources are allocated, by means of the price system, to the satisfaction of the things for which there is a money demand. Of course, even in the heyday of laissez faire there were some restrictions on anti-social consumption; for instance, we restricted the production of such commodities as drugs, alcoholic liquor, pistols, and adulterated food, even though a money demand existed for them. Restrictions have also been placed on the use of some of the factors of production. Thus, the hours of women and children, and now men, have been regulated; wasteful exploitation of our petroleum resources has been restricted; and controls have been placed on the flotation of capital issues. Despite 
these restrictions and the mutations of the free enterprise system introduced by the growth of monopolies and the fluctuations of the business cycle, our available supplies of land, labor, and capital are still, generally speaking, allocated to produce the goods for which there is the greatest money demand.

In normal times an increase in demand relative to supply led to an increase in price; this allocated the available supply to the highest bidder by cutting off the purchases of those unwilling or unable to pay the higher price. Allocation in peacetime is thus normally based on the price system. However, in wartime we do not allocate the factors of production and distribution solely in accordance with the determinations of the price mechanism. Departure from price allocation is caused by a changed environment created by the war crisis. The production task is so monumental and crowded into such a short space of time that the price mechanism becomes ineffective. The price mechanism is wasteful and inefficient as an allocator during the critical period of war.

For one thing, in wartime we cannot afford to have health and efficiency distributed in proportion to income. Yet that is the result of reliance upon price allocation alone. Thus, if we allowed the price of sugar to rise, the demand would ultimately boost the price to a high level. The per capita consumption of sugar by those with low incomes would drop accordingly. While that might not be important in the case of a single commodity, it would clearly be undesirable if it extended to many of our basic foods. It would lessen both the efficiency and morale of our civilian population needed for the war effort. In addition, the inflationary tendencies resulting from increased demand for the limited supply of civilian goods hinder and obstruct the war effort. Therefore, the Government has fixed a ceiling price for sugar and has begun to ration the supply of sugar in a fair and equitable manner among consumers. To help meet the food needs of the civilian population, the Government has subsidized the farmer to stimulate an increased supply of food. In addition, it has marketed food through the grocer under the federal surplus marketing agency and distributed food through community kitchens in order to serve the food needs of large sections of our population.

Conversion to military production is the great need of the time. And time is precious. Under the traditional price system, conversion would take place whenever the plant management decided that the bid for military production was sufficiently profitable and otherwise attractive to warrant the change over. Obviously, traditional price allocation is not well designed to speed conversion.

Price allocation produces waste too when our economy must conserve every ounce of strength. Thus, the bargaining power of large purchasers tends to exert such pressure on producers of raw materials that smaller purchasers, whose products may be more necessary to the war effort, cannot buy necessary materials. Thus, the automobile business of a steel company is so important business-wise that the favor of such a large customer is likely to be retained by the steel company at the expense of 
smaller customers, although they may actually be making products which are more important to prosecution of the war than passenger cars.

Allocation based on price determination is clearly not geared to the break-neck speed of a war economy. Consequently, planned allocation and direct price control have been substituted. Direct price control and planned allocation are supplementary governmental methods calculated to expedite and prosecute the war effort. Even when prices are legally imposed by a governmental agency, the problem of allocating the limited supply of a commodity becomes acute, because it is no longer possible to eliminate potential purchasers by means of a rise in prices. As a result, the distribution of the scarce commodity is likely to become quite erratic. It may be sold on a first-come-first-served basis; or the seller may limit each customer to some portion of his previous use, irrespective of the relative importance of the various uses. In such a situation it is possible for the relatively unessential uses to get most of the supply, if, as in the case of steel, the relatively unessential uses are also the largest uses. Inevitably, as the experience of other countries and of this country in the last war demonstrates, planned allocation of materials and products, where necessary, must be instituted. Thus, government enters the field of civilian supply.

\section{III}

The recognition of this need, through official action, was gradual, although the thought was never far away. The first step was taken on May 29, I940, when President Roosevelt, acting under authority of a statute passed in $1916,{ }^{1}$ created the Advisory Commission to the Council of National Defense. ${ }^{2}$ The work of three members of the Commission in charge of Consumer Protection, Price Stabilization, and Agriculture was related to the problems of Civilian Supply. Congress too showed increasing awareness of some of these problems and passed the Priorities Act which was approved by the President on June 28, $19400^{3}$ This Act laid the foundation for subsequent priority and allocation programs.

Approximately seven months after the creation of the Advisory Commission to the Council of National Defense, on January 7, I94I, the President issued an Executive Order No. $8629^{4}$ establishing the Office of Production Management (OPM). Within OPM a Priorities Board of six members was created. This Board was directed by the President to "make findings and submit recommendations with respect to the establishment of priorities," and was directed to "take into account general social and economic considerations and the effect the proposed actions would have upon the civilian population." Thus, the problems of civilian supply began to crystallize as the defense program took shape.

The emphasis of the work of the Priorities Board was on defense. Whatever was required for defense was taken for defense; only what was left over was available for civilian use. At first, when defense requirements were relatively small, systematic

\footnotetext{
139 Stat. 649 (r9i6), 50 U. S. C. $\$ 2$ (1934). ${ }_{5}^{2}$ Fed. Reg. 2 Ir 4 (I940).
}

54 STat. 676 (1940).

${ }^{5}$ FED. REg. 2 I I 4 (I940).
+6 FED. REG. I9I (I94I). 
allocation of the residual supply among competing civilian demands did not seem necessary and was not attempted. But as defense requirements expanded, it became clear that the available materials were not being distributed in the most equitable and efficient way.

To meet this situation the President on April Ir, I94x, created by Executive Order No. $8734^{5}$ the Office of Price Administration and Civilian Supply (OPACS). OPACS was ordered to "Take all lawful steps necessary or appropriate in order ... (3) to stimulate production of the necessary supply of materials and commodities required for civilian use ... and (4) after the satisfaction of military defense needs to provide, through the determination of policies and the formulation of plans and programs, for the equitable distribution of the residual supply of such materials and commodities among competing civilian demands." To carry out this responsibility, there was created within OPACS a Division of Civilian Supply, headed by an Associate Administrator.

The Division of Civilian Supply remained within OPACS until August 28, I941. On that date the President, by Executive Order No. $8875,{ }^{\circ}$ created the Supply Priorities and Allocations Board (SPAB) and transferred the Division of Civilian Supply to OPM.

This transfer of Civilian Supply from OPACS to OPM had little effect on the actual workings of the governmental machinery concerned with Civilian Supply. The Administrator of OPACS, now OPA, became the Director of the Division of Civilian Supply, now of OPM, and the Associate Administrator became the Deputy Director. The work of Civilian Supply had been clarified meanwhile by the passage of the Vinson Act $^{7}$ which gave the President priority and allocation powers over shortages in the supply of any material for civilian purpose. The groundwork for Civilian Supply programs was thus laid. And successive executive orders relating to the defense organization were increasingly detailed and acute with respect to civilian supply problems. Most recently, the replacement, on January I6, I942, of OPM and SPAB by the War Production Board (WPB) ${ }^{8}$ has not resulted in any material changes in the operations of the Division of Civilian Supply, except that WPB in turn has delegated to OPA the equitable rationing of products at the retail level. ${ }^{9}$

IV

The agency of Civilian Supply operates within a legal framework. The President of the United States, under his constitutional power as Commander-in-Chief of the Army and Navy and under the powers vested in him by a number of statutes (some adopted currently and some still on the books from World War I) has comprehensive authority over the allocation of materials in time of emergency.

\footnotetext{
'Id. 1917.

${ }^{\circ} I d .4483$.
}

'Pub. L. No. 89, 77th Cong., 1st Sess. (May 31, 1941), 55 Stat. 236, amending 54 Stat. 676 (1940). The text of the amended Act appears in $4 \mathrm{I}$ U. S. C. A. (Supp. 194I), p. $144 \mathrm{n}$, and I C. C. H. War Serv. \$3072I (1942).

8 FED. REG. 329 (1942).

${ }^{8}$ WPB Directive No. I, Release No. WPB-52, Jan. 27, 1942. 
The functions of the Division of Civilian Supply stem in large part from the Priorities Act of June 28, $1940,{ }^{10}$ as amended May 3r, 194I. ${ }^{11}$ The Priorities Act of June 28 , 1940 , authorized the President, in his discretion, to accord priority to deliveries of material pursuant to orders of and contracts with the Army and Navy over deliveries for private account or for export. Obviously this priority power was too narrow. It was broadened when Congress amended the Priorities Act by legislation called the Vinson Act on May 3r, 194r. ${ }^{12}$ The heart of the Vinson Act reads as follows: $:^{13}$

Whenever the President is satisfied that the fulfillment of requirements for the defense of the United States will result in a shortage in the supply of any material for defense or for private account or for export, the President may allocate such material in such manner and to such extent as he shall deem necessary or appropriate in the public interest and to promote the national defense.

The Act further provides: ${ }^{14}$

The President may exercise any power, authority, or discretion conferred on him by this section, through such department, agency, or officer of the Government as he may direct and in conformity with any rules and regulations which he may prescribe.

The power of delegation thus given to the President was exercised by him in the Executive Order of August 28, I94. ${ }^{15}$ By that order, the President conferred on OPM, "subject to such policies or regulations as the Supply Priorities and Allocations Board ... may from time to time determine," the power to "perform the functions and exercise all the power, authority, and discretion conferred upon the President by Public No. 89, 77th Congress, First Session, approved May 3r, r94I" (the Vinson Act). In this executive order dated August 28, 1944, it was provided in part:

5. Consistent with the basic defense policies of the President, the Supply Priorities and Allocations Board shall:

(a) Determine the total requirements of materials and commodities needed ... for ... civilian ... purposes; establish policies for the fulfillment of such requirements. ...

(b) Determine policies and make regulations governing allocations and priorities with respect to the procurement, production, transmission, or transportation of materials, articles, power, fuel, and other commodities among ... civilian ... demands of the total defense program."

To the Office of Production Management was given the duty of formulating plans and programs providing for allocations and priorities with respect to civilian and other goods and of submitting them to the Supply Priorities and Allocations Board for approval or modification. It was also provided that:

7. There shall be within the Office of Production Management a Division of Civilian Supply to be in charge of a Director appointed by the Office of Production Management with the approval of the President. The Division of Civilian Supply shall represent civilian interests relating to the supply and priority activities of the Office of Production Manage-

\footnotetext{
${ }^{10}$ Supra note 3.

12 Ibid.

14 Ibid.
}

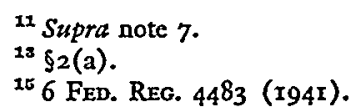


ment. It shall formulate plans and programs providing for the equitable distribution among competing civilian demands of the materials, articles, power, fuel, and other commodities made available by the Supply Priorities and Allocations Board for civilian use. Such plans and programs shall be submitted through the Office of Production Management to the Supply Priorities and Allocations Board for approval or modification.

The power thus given to OPM-and through OPM, to the Division of Civilian Supply-was a broad one. The Vinson Act expressly referred to "a shortage in the supply of any material ... for private account," an expression clearly intended to apply to civilian needs. However, if there was any doubt about the meaning of this statutory language, its underlying legislative history dispelled that doubt. In the Senate Report recommending passage of the Bill, the following statement appears in a "summary of purposes of the Bill":

[The Bill is designed] . . . to promote control of the distribution of those products and materials in which shortages appear by reason of the impact of the defense program and to promote the allocation of such production and materials to defense and to the most important civilian needs in preference to less important uses. ${ }^{16}$

Similar statements were made during the course of hearings on the Bill. For example, Mr. Stettinius, then Director of Priorities, made the following statement before the Senate Committee on Military Affairs: ${ }^{17}$

Where such shortages occur, inevitably the balance available for civilian consumption is insufficient to cover all civilian needs. It therefore becomes necessary, when such shortages occur, to direct the distribution of the balance, after fulfillment of defense needs, in order that the supply left may be used for the more important civilian needs rather than to allow it to be consumed in non-essential uses.

In the House of Representatives, statements similar to those made in the Senate appear. Thus, Representative Vinson, sponsor of the Bill, said:18

It is very important, therefore, that authority exist for allocating from available supplies, first, to fill vital defense requirements, and secondly, to civilian needs in the order of their importance.

It was thus made clear that the powers given to the President by the Vinson Act were to be used to allocate materials to civilian needs in the order of their importance. In addition to this, the legislative history of the Act shows plainly that the power to allocate may be exercised both in cases of actual shortage and in cases of anticipated priorities or allocations program. For power to deal with shortages only after they occur would be tantamount to locking the barn door only after the horse is stolen. That the Vinson Act gave the President power to foresee the possibility of the horse being stolen was pointed out by Representative Vinson, who, in reporting the Bill to the House, said:19

\footnotetext{
${ }^{10}$ Sen. Rep. No. 309, 77th Cong., Ist Sess. (I941) 6.

${ }^{27}$ Hearings before Sen. Committee on Military Affairs on H. R. 4534, 77th Cong., Ist Sess. (1941) 33.

${ }^{18} 87$ Cong. Rec. 3801 (May 8, 1941). ${ }^{19} 87$ Cong. Rec. 3801 (May 8, 194I).
} 
... a priorities system ... must contain safeguards against acute shortages of essential materials arising. An effective safeguard will provide for taking steps to conserve the supply of such materials before the shortages become acute.

Under the broadest interpretation of Section 2(a) the best that can be done now is to exercise ... control over ... materials ... in which acute shortages have occurred. That is not sufficient.

The same view was advanced clearly by $\mathrm{Mr}$. Geoffrey Smith, Counsel, Priorities Division, Office of Production Management, in the hearings on the Bill, in which he said:20

This will give the President, or whatever agency he assigns the power to, the right to foresee a shortage before it becomes acute and take the necessary steps to prevent it from becoming acute. That is a very important authority that we badly need at the moment, because as the impact of this program hits us, there are in various fields more and more areas where you can see on the horizon a shortage that has not become acute as yet.

This thought appears also on page 5 of the Senate Report on the Bill, where it is stated that the Bill gives "confirmation of the right to deal with acute shortages, and further to conserve the supply to prevent acute shortages." This power to anticipate shortages as well as to deal with existing shortages is very necessary to effective administration of priorities and allocations under the Act. Since the power given is so complete, there is no need for a meticulous distinction between orders brought about by existing shortages and orders brought about by anticipated shortages. In the nature of things, such a distinction would be unreal, and the language of the Act fortunately makes it unnecessary to draw such a distinction.

The basic statutory power found in the Vinson Act was expressly delegated by the President to SPAB by the Executive Order of August 28, I94I. Recently, by Executive Order dated January I6, 1942,21 the President created the War Production Board. To the Chairman of this Board, the President delegated, among other things, the power to:

Perform the functions and exercise the powers vested in the Supply Priorities and Allocations Board by Executive Order No. 8875 of August 28, r94I.

Thus, these basic priorities and allocations powers now reside in WPB.

Until recently, the Vinson Act was applicable to shortages in the "supply of any material" and provided for the allocation of "such material." The Executive Order of August 28, r941, containing the basic delegation of power refers to distribution among competing civilian demands of the "materials, articles, power, fuel, and other commodities." The question has arisen whether the term "material" used in the Vinson Act was meant to be as broad as the President's order of delegation asserts. Unquestionably the Vinson Act was intended by Congress to be comprehensive legislation on priorities and allocations to assure an orderly and effective defense production. The statute was written in broad terms. And it contained broad delegation of power

\footnotetext{
${ }^{20}$ Hearings before the House Committee on Naval Affairs on H. R. 4534, 77th Cong., Ist Sess. (April 28 , rg4I) 1000.

${ }^{21} 7$ Fed. Reg. 329 (1942).
} 
to the President. Under these circumstances, it would seem that the term "material" must have been used in its broadest sense. The governmental agencies have proceeded on that basis. Recently an amendment to the Priorities and Vinson Acts, which would clarify this problem was adopted by Congress in the Second War Powers Act. ${ }^{22}$ The amendment is applicable to shortages in the supply of "any material or of any facilities" for defense or private account and provides for allocation of such "material or facilities." The addition of the term "facilities" removes any doubt concerning the breadth of the priority and allocation power.

\section{V}

Decisions regarding allocation, when made, have been carried out by three broad types of order. Priority or $\mathrm{P}$ orders are granted to war or essential civilian industries to insure that all their requirements for materials are satisfied first. In effect, then, $\mathrm{P}$ orders determine who shall go to the head of the line waiting for scarce raw materials. Limitation or L orders, on the other hand, determine who shall be forced out of line, in part at least. They have been applied mostly to end-products in the form in which they are bought by the ultimate consumer, and have the effect of reducing the demand for all the materials embodied in the restricted end-products. Finally, there are conservation or $\mathrm{M}$ orders. These apply to a single scarce raw material, limit certain of its uses, and thus provide a mechanism for allocating the available supply.

Statutory authority for these various types of orders may be found in the Priorities Act which provides that "priority" may be "assigned to deliveries . . . under contracts or orders ..." and that the President may "allocate . . . material." These various types of orders are designed to reinforce the priorities and allocation system authorized by Congress. Although there is no express statutory direction to use these types of orders, it would seem that they can be supported as appropriate methods to effectuate the statutory priority and allocation powers.

These various types of orders should be distinguished from the preference rating which they sometimes contain. ${ }^{23}$ A preference rating is often attained as a result of an individual application in connection with a given transaction, on forms known as PD-I's. Most P orders, however, confer a blanket preference rating on the purchases of all sorts of materials by an industry whose products are considered to be especially important. For example, Order P-56 applying to mine operators, granted such producers an A-I-A rating on the purchase of material needed to repair a mine in the event of actual shutdown, a rating of A-I-C on the purchase of materials necessary to prevent an imminent breakdown, and an A-3 rating on general items of mining equipment. This latter can be applied, by all qualified mine operators, to the purchase of a wide variety of materials needed for mining operations.

Although sometimes they have been accompanied by a $\mathrm{P}$ order giving a preference rating to enable the industry to obtain the materials necessary to undertake the per-

${ }^{22}$ Pub. L. No. 507, 77th Cong., 2d Sess., approved March 27, r942.

${ }^{23}$ Preference ratings run as follows: $A A, A-I-A$ to $A-I-J, A-2$ to $A-r O, B-I$ to $B-8$. The "B" ratings are generally used to distribute small amounts of scarce materials available for civilian industrial uses. 
mitted production, in most cases $L$ orders are not accompanied by any preference ratings. Instead they serve to reduce the demand for scarce materials by limiting the production of, and therefore the use of such materials by, industries whose products seem relatively unessential. For example, L-2I curtailed the production of automatic phonographs and weighing, amusement, and gaming machines. Production of the first three was cut $25 \%$ of the base period production for the year ending June 30 , I94I, in December, $50 \%$ in January, and $75 \%$ thereafter, while gaming machines were cut $50 \%$ in December, $75 \%$ in January and prohibited thereafter. The effect of these limitations was to reduce the demand for and thereby conserve the supply of such scarce materials as copper, aluminum, bakelite, as well as steel.

$M$ orders apply to a particular material and either allocate it completely or control certain of its uses. For example, M-2I-d prohibits the use of corrosion and heat resistant chrome steel in the fulfillment of orders bearing a preference rating of less than A-ro (except in the case of articles already fully fabricated). The effect of this order was to confine the use of chrome steel to uses which had received a preference rating and prevent chrome steel from going into a wider variety of products, especially consumer electrical heating appliances, which were felt to be comparatively unessential uses of this highly critical material.

At the start of the defense program $\mathrm{P}$ orders were used to insure that companies making defense products should be served first. As we started with a certain amount of unused capacity, it was at first possible to divert materials to defense production without cutting down on other uses. In a short time, however, it became clear that certain materials, especially aluminum, were going to become extremely scarce. In the case of such materials, the preference rating system did not work very well. An industry which, for example, was rated A-2, was often allowed under the preference rating system to obtain all of a scarce material it wanted before an industry rated A-3 was allowed to obtain any. In such cases resort was had to $M$ orders. To begin with these orders were often able to balance supply and demand by eliminating or restricting relatively unessential uses of a scarce material. But as the shortage became acute it became increasingly necessary to allocate all of a given material-in other words, OPM had to determine from month to month each of the specific uses to which the material could be put and the amount available for each use. Still later, as scarcity became widespread, $\mathrm{L}$ orders were used to reduce the demand for all the materials going into relatively less essential civilian products.

Until quite recently, therefore, the Division of Civilian Supply has been mainly concerned with freeing materials for the defense effort by aiding in the issuance of orders designed to restrict the production of relatively less essential civilian products. Among the outstanding consumer durable goods which have been restricted are passenger cars, mechanical and ice refrigerators, and cooking and heating stoves. That the civilian population can get along without them in time of emergency and that such existing goods can be made to last longer was demonstrated during the depression and undoubtedly will be demonstrated again during the present war. A 
somewhat detailed examination of the $L$ orders which were issued to curtail the production of these goods will indicate the general methods which were used.

The first limitation order on automobiles was issued on September 13, 194r. ${ }^{24}$ The three largest producers were, during the four months from August through November, restricted to $60 \%$ of their output during a three-year base period running from August I, I938, to July 30, I94I. Smaller producers were curtailed to $85 \%$ of their average production during the same period. Production of cars for certain government purchasers and for export to countries covered by Lend-Lease arrangements was, by a later interpretation, ${ }^{25}$ excluded from the quotas. Production was left approximately unchanged during December, but toward the end of the month was cut a further $25 \%{ }^{26}$ At this time it was proposed to cut January production to $50 \%$ of the original December quota. Later, however, production at $100 \%$ of the December quota was permitted, ${ }^{27}$ but at the same time complete cessation of production after January (except for a ro-day grace period until February ro) was ordered. On January i a general limitation on the sale, delivery or transfer of passenger cars was put into effect to conserve the existing stock, and also the cars produced during January, for essential uses. ${ }^{28}$

Domestic mechanical refrigerators were first limited on September 30, 194r. ${ }^{20}$ The limit imposed varied with the relative size of the manufacturer. Those manufacturers whose monthly average factory sales for the base year (the year ending June 30, I94I) exceeded I6,000 units were limited during each month from August through December, to $55 \%$ of their average monthly production during the base period; while manufacturers producing between 5,000 and r6,000 units were allowed a monthly average of $7 \mathrm{r} \%$ of their monthly production during the base period. These quotas were reduced further for January and February of 1942 to monthly averages of $48 \%, 60 \%$ and $70 \%$ of monthly production during the base period. ${ }^{30}$

Manufacturers of domestic ice refrigerators were also limited, but in a different manner. During the period from September I, I94I, through November 30, r94r, the use of steel in the production of ice refrigerators was limited to a monthly average of $65 \%$ of the monthly average use during the year ending June $30,194 \mathrm{r}^{31}$ This type of order is aimed at input of raw materials into the industrial plant rather than output of end-products made from the material in the plant. Control was placed on steel used rather than units produced because manufacturers had wood-working equipment and so could use wood instead of steel in the making of refrigerator boxes.

Another order using input control restricted the quantity of iron and steel going into domestic cooking appliances. Here again the degree of curtailment depended on the relative size of the producers. Manufacturers whose factory sales during the base period were between $\$ 1,000,000$ and $\$ 3,000,000$ were cut to $69 \%$, and those whose

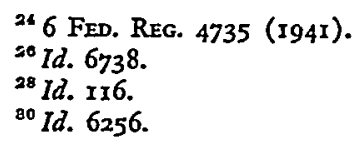

${ }^{20} I d .6683$.

${ }^{27} 7$ FED. REG. 473, 515 (1942).

${ }^{20} 6$ FED. REg. 5008 (1941).

${ }^{31}$ Id. 5534. 
sales were less than $\$ 1,000,000$ were cut each month to $70 \%$ of average monthly production during the base period. 32

In all, by the first of this year, $20 \mathrm{~L}$ orders had been issued, ranging all the way from restrictions on the use of electric power in the southeast and the consumption of waste paper by paperboard plants in the east to restrictions on the production of vacuum cleaners, vending machines, and farm equipment. In two thirds of the orders restrictions were placed on the output of finished products, while input of raw materials was controlled in the remainder. In a number of cases, however, where main reliance was placed on output control, input control was also used to restrict the production of replacement parts, body trim, and the like. Of course, control of the output of finished products indirectly tends to control the input of raw materials. With the exception of the passenger car industry, where definite quotas for each company were provided, production was restricted to some percentage of a given base period (although minimum absolute quotas were sometimes added to prevent, where different cuts were provided for different size firms, the top of one class from receiving a larger allowance than the bottom of the preceding class). In most cases, production for defense purposes was included in the limitation, because the items covered were usually ones in which defense production was not important. In a few cases where such production was important, however, it was excluded from the limitation to enable the Government to buy on favorable terms. Finally, in about half the orders, restriction was uniformly applied irrespective of the size of the firm; but in the other half the output of large companies was curtailed more than that of smaller firms, ${ }^{33}$ on the theory that large companies could more easily obtain defense contracts, had the engineering ability to convert to defense work, and possessed the financial resources to make the change. In some cases, as many as four size classes of firms were distinguished, with different cuts applied to each of the classes.

\section{VI}

These various types of orders have been developed to effectuate policies designed to meet the priority and allocation problems of the defense and war programs. The earliest priority and allocation problems that presented themselves for determination involved few difficulties. The first actions under the priority powers were merely determinations to give priorities on delivery to accepted orders of the nation's armed services over other orders. Among the military orders themselves, there was at first practically no problem of priority. Meanwhile, the Army and Navy Munitions Board provided machinery for determining priorities among military orders. This Board began to meet the growing priority problems created by increased military orders by rating the relative urgency of articles of war. It was intended that the contracting

${ }^{32}$ Id. 6425 .

${ }^{3 a}$ Many allocations of materials involve distribution of different quotas to different civilian users. The question of discriminatory distribution may therefore arise. It would seem, however, that if expert administrators have concluded in good faith that the quota distribution is reasonable, the allocation would be upheld. See, e.g., Railroad Commission of Texas v. Rowan and Nichols Oil Co., 3 10 U. S. 573 (I940); Terminal Taxicab Co. v. Public Utilities Commission of the District of Columbia, 24 r U. S. 252 (1916). 
officers of the armed services could automatically apply the priority ratings to a "critical list" of materials required for the manufacture of the articles contracted for by the armed services. This "critical list" was determined by the current priorities agency (first the Advisory Commission to the Council of National Defense, then OPM, now WPB) upon recommendation of the Army and Navy Munitions Board. The "critical list" expanded as the defense program grew until it finally aggregated some 300 items.

After this initial priority system was in operation for a time it became apparent that the scope of priority orders, together with the expanded civilian purchasing largely stimulated by the military expenditure, was causing increasing difficulty in fulfilling essential civilian requirements. This was especially so in the case of certain metals such as aluminum and nickel. Efforts to remedy this situation were made by attempting to classify the civilian uses in an order of relative importance corresponding to the order of relative importance among the military uses. Thus was born the system of ratings beginning with A-r for items of the greatest military urgency and ending with B-8 for items of supposed minimum essential civilian importance. In addition to such attempts at automatic classification there was a constantly growing number of individual applications for preference ratings.

By the beginning of last summer it became apparent that unrestricted civilian demands, coupled with the gradually increasing military requirements, would result in substantial shortages of basic commodities like iron and steel. It was further apparent that no plans likely to come to fruition would overcome this shortage. Accordingly the Civilian Supply Division, then a part of OPACS, considered what action might be appropriate to cope with this new development. It became convinced that the system of preference ratings was an inadequate method of dealing with the problem. For one thing, the generalized rating by which all demands of any one class are preferred to any demands of any class lower in rank is workable only while the effect of the preference is at most delay in delivery of the less preferred articles. However, increasing shortages made it apparent that the time was near when failure to obtain a relatively high preference rating would mean inability to obtain the necessary material altogether. Moreover, under such circumstances all the available supply of certain critical materials would be distributed only under rated orders. This, of course, meant a vast number of ratings. And since ratings were handled largely piecemeal, total perspective was lacking. The administrative difficulties of controlling ratings were thereby heavily increased. In fact, by last summer the accumulation of A-I ratings had already become so vast that it was necessary to subdivide A-I into A-I-a to A-I-j, inclusive, in order to assure prompt delivery on urgent military orders. In addition, there was then no requirement that an order, however rated, be accepted by the producer, manufacturer or supplier. ${ }^{34}$ Thus the priority

\footnotetext{
${ }^{34}$ This was subsequently changed in August 1941 by Priorities Regulation No. I, 6 FED. Reo. 4489 (I941), so that acceptance of defense orders became mandatory, subject to certain exceptions.

The Second War Powers Act provides: ". . . the President may require acceptance of and performance under such contracts or orders [generally, Army, Navy, Lend-Lease, and contracts or orders which the
} 
rating was no assurance that the person requiring materials for an essential purpose would succeed in placing his order and thereby obtain the benefit of the rating.

In view of these considerations the Division of Civilian Supply concluded that additional and more direct methods were required. Instead of eliminating or curtailing unessential uses by granting preference ratings for essential uses, it appeared feasible to prohibit directly either the manufacture of an unessential article or the use of critical materials in that article. In other words, direct limitation of production of unessential products was inaugurated. Thus was born the limitation order.

The first application of this approach was in the field of consumers durable goods. The available information at the time indicated a shortage of iron and steel of at least five million tons. After study, it was concluded that this shortage could be dealt with administratively by limitations upon the production of consumer durable goods and nonmilitary construction, both large users of iron and steel and relatively unessential to the civilian economy. Further study of the consumer durable goods field was made, and in July r941 a tentative program was announced by OPACS for curtailing the production of automobiles, refrigerators and washing machines. Coupled with this announcement was a statement that additional curtailment programs for other consumer durable goods were under consideration. Limitation orders in this field were subsequently put into effect. ${ }^{35}$ These limitation orders, of course, had their limitations. They were devised merely to cut off unessential demands. They did not deal directly with meeting essential requirements. As then used, the limitation order was adopted without study of the total factors affecting supply and demand of other materials and products.

The next step in the evolution of defense administration of priorities and allocations came about in the farm equipment field. This was the first substantial effort to determine essential requirements of an important civilian industry and to fix production goals to meet those requirements. The Division of Civilian Supply based the farm equipment program on the production goals for farmers set by the Secretary of Agriculture. These production goals were translated by Civilian Supply into terms of equipment necessary to fulfill the program. In turn, the necessary farm equipment was translated into terms of the raw materials required to produce the equipment. It was originally intended that these required raw materials would be earmarked for farm equipment by appropriate orders. However, this did not take place. Instead, the farm equipment program was fitted into the preference rating and limitation order system. A-3 ratings were given to farm equipment and L orders were adopted to prohibit production of such equipment beyond established quotas. Although this method was a step forward in the administration of priorities and allocations, it too had its shortcomings. For one thing, it failed to give adequate

President shall deem necessary or appropriate to promote the defense of the United States] in preference to other contracts or orders for the purpose of assuring ... priority." (Statement in brackets supplied.) ${ }^{3 x}$ Since then, of course, the limitation orders in the consumers durable goods field have increased in number and have become progressively more drastic in curtailment until production of some of these civilian goods has been prohibited entirely. 
consideration to the material requirements of other essential civilian products. For another, it did not give sufficient consideration to the supply and demand factors of the affected materials. Finally, the preference rating system gave only limited assurance of obtaining the necessary materials for farm equipment.

These methods, with their short cuts, were inadequate as a total method for allocating scarce materials among competing civilian demands. Therefore, the Division of Civilian Supply has recently developed total programs which consider at one time the supply and all of the demands for a scarce material, and also attempt to consider the relations to the other factors entering into the production and uses of the different products.

Current civilian allocation programs have been developed by and large as follows. The total current supply of the scarce material is estimated. As against the total supply, total requirements are estimated-including demands of the Army and Navy, defense plant and defense housing programs, maritime program, Lend-Lease, other exports, and civilian. The requirements other than civilian are primarily the responsibility of other government agencies like the Army, Navy, Maritime Commission, Lend-Lease Administration, and the Board of Economic Warfare. Yet the Division of Civilian Supply obviously must take these other requirements into consideration in determining civilian allocations. Civilian requirements, of course, include not only the needs of the ultimate consumer but also the demands of those industries which are not engaged in direct military production. Similar supply and requirements studies are made with respect to the other scarce materials so that allocation programs may be coordinated.

The problem of allocation is to determine and satisfy the relatively more essential needs out of the inadequate supply. First things are put first. Direct military needs are generally satisfied first. Yet there are occasions in which the civilian uses are equally essential to prosecution of the war effort. Thus, the use of tungsten in tool steel for war production is as important, if not more important, as its use in armorpiercing shells. The Division of Civilian Supply may therefore ascertain basic minimum civilian requirements which constitute an irreducible minimum claim on the supply of material. When the supply of the material available for civilian use is determined, that portion of the pie is then ready for allocation among competing civilian demands.

The allocation among civilian uses is generally based upon detailed schedules of end-product uses of the material. Extensive information is collected to aid in determining these allocations. Once the necessary information has been assembled, the allocation among competing civilian demands is made. The primary purpose of any civilian allocation program is to distribute the material or products so that more essential, rather than less essential, civilian needs are met first and so that the burden of shortage is minimized.

A list of criteria considered in making allocations among competing civilian demands would be excessively long. Of course, it is impossible to apply precise 
formulae in weighing the various criteria used. Allocation is a comparative, not an absolute, process. A few of the relatively simple standards are set forth in the margin below. ${ }^{36}$

VII

I. The Evolving Procedures for Priorities and Allocation. Thus far, the substantive considerations which enter into the formulation of priorities and allocation programs have been discussed. We now turn to the procedures whereby these programs are determined.

The statutory basis for allocation of materials is general with respect to the standards to be observed, and is completely silent as to the procedure to be followed in making determinations. It is doubtful that either the absence of more specific standards or the absence of any procedural requirements presents a substantial legal problem. However, the form of the legislation does cast upon the affected government agencies the burden of making appropriate provision for the performance of their duties without guidance or directions from Congress.

The procedures followed during the early development of the defense program involved primarily internal considerations among government officials. From the outset, however, there was extensive informal discussion with members of affected industries and labor groups. As defense activities increased, machinery was devised for obtaining more regularized discussion with representatives of industry and labor. To that end a formal bureau was set up in OPACS for the purpose of establishing lists of representatives of private groups who might be consulted advantageously with respect to problems then before the agency. As the defense program has grown into a war program there has been considerable evolution in the development of procedures. The development cannot be regarded as completed, however, and it is certain that further changes will take place.

As presently organized, the Division of Civilian Supply does not issue orders or regulations. The orders and regulations are issued by the Chairman of the WPB or

${ }^{36} \mathrm{x}$. Less material is allocated to a product utilizing a large quantity of the material in relation to its functional use than to a product which has greater functional use in relation to unit consumption of the material.

2. More material is allocated to a product which is by nature largely functional than to a product which has a decorative, nonfunctional purpose.

3. Less material is allocated to an industry which can be readily converted to war production than to an industry where curtailment, because of the impossibility of conversion, would entail extensive labor displacement with small opportunity for reabsorption of labor.

4. More material is allocated to a product which is by nature a collective facility serving a large number of people, such as commercial cooking equipment, than to a product used primarily in a single household, such as domestic cooking equipment.

5. Less material is allocated to a product in which the possibility of substitution of less scarce materials is feasible.

6. More material is allocated for replacement purposes to a product which requires a large annual replacement than to a product which is highly durable.

7. The allocation of the material involved is adjusted in consideration of external limiting factors such as shortages of other necessary component materials.

8. Aore material is allocated to a product which constitutes subsidiary equipment for the production or operation of several end-products than to a product in which the material is consumed for a narrow or highly specialized function. 
by his agent, the Director of the Division of Industry Operations. It should be borne in mind, therefore, that the administrative procedures of the Division of Civilian Supply which lead to orders or regulations merely gear into the over-all procedures of the WPB. This is shown by the steps leading to effectuation of a civilian allocation program. When tentative programs have been drawn up by the Division of Civilian Supply, they are discussed with other divisions of WPB as well as other interested government agencies. In the course of working over those plans representative groups of the industries and labor unions affected may be called in through the Division of Industry Operations and the Labor Division for advice and suggestions. When the plans of allocation are formulated they are presented to the Requirements Committee of the WPB. This Committee consists of representatives from the War Department, Navy Department, Office of Lend-Lease Administration, Board of Economic Warfare, Maritime Commission and the Division of Civilian Supply, with a chairman deputized by the Chairman of the War Production Board to determine questions before the Committee. The Committee has the duty of determining and approving programs for the allocation of available supplies of essential and critical raw materials and industrial materials among the various claims represented by the committee members. Its recent formation represents a significant step towards development of over-all programs. If the Requirements Committee approves the allocation program, it is then sent to the Director of Industry Operations. In the Division of Industry Operations the program is put into the form of a proposed order or orders which seek to effectuate the program. After clearance with other interested divisions of WPB, the proposed order is then sent to the Bureau of Priorities. At this point a Clearance Committee has been established to advise the Chief of the Bureau and the Director of the Division of Industry Operations on proposed orders. The Clearance Committee is a representative body with members from the Army and Navy Munitions Board, the Division of Civilian Supply, the Labor Division, the Division of Industry Operations and the Materials Division, and has for chairman the Deputy Chief of the Bureau of Priorities. If adopted, the proposed order is submitted to the Chairman of the WPB or to the Director of the Division of Industry Operations, to whom the Chairman of the WPB has delegated much authority in this regard. If approved by the Chairman of the WPB or his agent, the order is ready to go into effect. The order, when effective, is administered by the Division of Industry Operations or the Division of Materials, depending upon the type of order.

Informal procedure is the warp and woof of administrative practice at WPB. Procedures are not yet entirely set: they are undergoing continual revision as the agency itself organizes to meet production goals. Formal procedure, as it has been developed in courts of law and certain administrative agencies, ${ }^{37}$ has not been used

\footnotetext{
${ }^{37}$ In general, the administrative procedures followed by the War Production Board are not similar to those of regulatory agencies like the Securities and Exchange Commission and others. The administrative procedures followed by the regulatory agencies are outlined broadly in the statutes which created the agencies. There is no statute laying down the bare fundamentals of procedure for the WPB.
} 
at WPB. Formal procedures, consisting of notice, hearings in which testimony under oath is taken subject to the right of cross-examination and is embodied in a formal record to which the agency is limited in reaching its decision, oral argument supplemented by written briefs, and formal findings of fact and opinion, are an outgrowth of the adversary system of our judicial process. Recognizing the adversary nature of many proceedings ${ }^{38}$ before them, some administrative agencies have adopted modified judicial procedures. Adversary proceedings, except possibly for suspension order cases, are not common at the WPB. There is therefore less reason for formal processes in operation. Moreover, the sheer volume of decisions alone would make it impossible to gain added protection to the person whose rights are being decided by formalizing proceedings before the WPB. Efficient administration of the war production effort could not survive a procedure which called for formal hearings in cases of controversy. WPB decisions deal with highly volatile situations created by a swiftly changing economy, and delay may mean disaster to the national interest. In addition, the necessity for immediate operation of decisions makes it imperative to act decisively through quick, decisive, flexible procedures. ${ }^{39}$ Even in normal times, of course, the informal method of procedure has been used extensively by administrative agencies to determine private rights. ${ }^{40}$

However, there is still a good deal of room for regularizing procedures in the War Production Board without formalizing them to an extent inconsistent with efficient administration. In fact, regularity of procedure should help expedite administration. Irregularity of procedure results in confusion and lack of policy. A good deal of work is being done currently in regularizing procedure, particularly in connection with appeals procedure. It will be helpful in the functional operations of the War Production Board itself as well as in letting outsiders know what procedures they must follow in requesting relief.

A general set of procedural rules and regulations of the WPB might be valuable in this respect. ${ }^{41}$ Some attempts in that direction already have been made. Thus, Priorities Regulation No. I and subsequent additions attempted to lay down a general framework for operation of the priorities system. However, this type of regulation related primarily to substantive, rather than procedural, matters. Procedural machinery has at times been blocked out in WPB orders themselves, particularly in $M$

${ }^{28}$ See U. S. v. Morgan, 304 U. S. I (1938).

${ }^{80}$ As Judge Learned Hand, then a United States District Court judge, put it in discussing the President's power to seize cables during the last war: "[The President] ... had to act quickly, certainly, and without the trammels of courts or private interests." Commercial Cable Co. v. Burleson, 255 Fed. 99, I04 (S. D. N. Y. I919), rev'd on other grounds, 250 U. S. 360 (1919).

${ }^{10}$ Report of the Attorney Generaj's Comattiee on Administrattve Procedure, Sen. Doc. No. 8, 77th Cong., Ist Sess. (I94I) 36 et seq.

${ }^{11}$ It is noteworthy that the Price Administrator has issued Procedural Regulation No. I governing the procedure for the issuance, protest and amendment of maximum price regulations. This regulation was issued under the provision of $\$ \$ 201$ (d) and 203(a) of the Emergency Price Control Act of 1942. Since the Act itself spells out a broad procedure, the regulation merely fills in the skeleton.

OPA has also promulgated tire rationing regulations, but these regulations were issued under the priorities and allocation powers set forth in the Vinson Act and delegated to it by the WPB under WPB Directive No. $x$ and Supplemental Directive No. IB. Fed. Reg. Doc. 42-1336, filed Feb. I3, I942. 
orders. However, these procedures do not relate to the issuance of orders. Recently, there have been a series of internal administrative orders which further clarify procedures and functions within the WPB. And through the adoption of clearance forms the procedural routes within WPB have been further regularized. However, the adoption of a general set of procedural rules and regulations would help tie these previous efforts together and establish rules of practice for the outsider. The problem is to evolve rules of procedure and practice which are both sufficiently flexible to enable the WPB to execute its functions effectively, and sufficiently regular and uniform to afford persons whose rights and interests are affected a fair opportunity to present their views. When such procedural rules are evolved, they will tend to ensure uniformity of treatment and to diminish the chances of arbitrary action. Although the task might not be easy, the effort in that direction should prove valuable in administering the war effort

2. The WPB Procedures and Due Process. The United States Supreme Court has laid down minimum standards for administrative procedures to meet the requirements of due process of law. These standards are not yet clearly defined. And their application to an executive agency like the WPB during war-time is not yet established. As pointed out above, most of the administrative procedures arising out of adversary proceedings are inapplicable to WPB actions; in so far as concepts of due process stem from adversary processes, they would seem inapplicable to actions of the WPB.

Generally speaking, adequate notice, opportunity for a fair hearing, and statement of findings seem to be the basic elements of due process in administrative procedure. The WPB has followed the practice of giving notice and affording an opportunity for hearing to interested groups, so far as possible, in formulating its programs and issuing its orders. Industry and labor advisory committees have been organized to represent persons affected by proposed orders. And appeals procedures have been provided for individual persons who seek relief from operation of orders. Of course, many orders apply to such large and sometimes indefinite numbers of persons that notice and hearing are impracticable. ${ }^{42}$ Thus, order M- $-\mathrm{-c}$ restricting the use of copper curtailed so many uses of the metal that it would have been impossible to notify and accord a hearing to all persons affected by the order. With respect to findings, the United States Supreme Court in Panama Refining Co. v. Ryan ${ }^{43}$ held that an executive order prohibiting the interstate shipment of "hot oil" violated the due process clause because it contained no statement of findings whereon it was based. However, the Court expressly excepted from its requirements of findings executive action which appropriately belongs to the executive province and is not subject to judicial review. ${ }^{44}$ Mr. Justice Cardozo entered a vigorous dissent to the holding of the majority in the Panama Refining case, stating: ${ }^{45}$

\footnotetext{
${ }^{12} \mathrm{Cf}$. Bi-Metallic Investment Co. v. State Board of Equalization, 239 U. S. 44r, 445 (1915).

${ }^{43} 293$ U. S. 388 (1935); cf. U. S. v. Baltimore \& Ohio R. R., 293 U. S. 454 (1935).

4" Panama Refining Co. v. Ryan, supra note 43 , at $43 \mathrm{I}-433$.

${ }^{45} I d$. at 448 .
} 
If findings are necessary as a preamble to general regulations, the requirement must be looked for elsewhere than in the Constitution of the nation.

The views of Mr. Justice Cardozo perhaps influenced the Court in a subsequent decision in which it limited its requirement of findings. ${ }^{46}$ In any event, it is not clear from the opinion in the Panama Refining case whether reasoned conclusions or mere formal findings are required by the due process clause. It is customary in the issuance of WPB orders to recite briefly in a preamble a general statement of considerations which have impelled the issuance of the order and to make findings pursuant to the standards set forth in Section 2(a) of the Vinson Act.

The procedure followed by WPB may become clearer by considering each type of order separately. The $\mathrm{P}$ order granting priority assistance is generally a blanket order covering a group of persons or an industry at large. After promulgation of the $\mathrm{P}$ order, individual persons may qualify for the preferred categories set forth in the order. When priority ratings are conferred by the WPB in an over-all P order, there would not seem to be any acute problem of due process. Just as the Government is free to award its contracts, the Government may confer a preferred status upon industries according to a priority scale. Moreover, any private person who sought to challenge the order would seem to be without standing to do so. ${ }^{\mathbf{4 7}}$

Individual applications for preference ratings for projects or for particular materials or facilities may raise a different question. These applications for priority assistance are passed on individually. The grant of priority assistance is a favor conferred upon the applicant. And if the favor is conferred there can be no question but that the applicant has no standing to raise any question concerning the due process of the priorities procedure. Nor is it likely that the applicant would seek to raise any such question. A more difficult problem arises where the applicant's request is denied. The adjudicative process is informal: formal hearings are not provided. Since the priorities system is a method by which the Government confers favors upon those regarded as relatively essential to success of the war program, it may be argued that denial of such favor does not entitle the applicant to question the procedure whereby decision was reached. On the other hand, it may be argued that the priorities system is more than a favor-conferring technique, that it operates effectively to apportion scarce materials, services and facilities among applicants and may result in economic injury to the applicant. Yet even if the priorities system is, in effect, an allocation system, the resulting economic injury to applicant from rejection of his application does not necessarily entitle him to challenge the decision. The statutory standards for priorities decisions are laid down in the Vinson Act ${ }^{48}$ where it is stated that:

... the President may allocate ... material in such manner and to such extent as he shall deem necessary or appropriate in the public interest and to promote the national defense.

\footnotetext{
${ }^{40}$ Pacific States Box \& Basket Co. v. White, 296 U. S. I76 (1935).

${ }^{47}$ Cf. Perkins v. Lukens Steel Co., 3 ro U. S. I13 (1940).

${ }^{48}$ Supra note 7, \$2(a).
} 
Economic injury to a private applicant is not a separate and independent element of the statutory standard to be taken into consideration in determining whether a priorities application should be granted or denied. As the Supreme Court indicated with respect to the broadcast station licensing powers of the Federal Communications Commission under the Communications Act of 1934, as amended:40

Plainly it is not the purpose of the Act to protect a licensee against competition but to protect the public.

However, even if the applicant has standing to challenge the procedure, it would seem that the absence of formal processes in denying such applications is not a denial of due process. Similar informal procedures have been used in administrative agencies for some time in passing upon applications for licenses. ${ }^{.0}$

$\mathrm{L}$ and $\mathrm{M}$ orders are not like the typical orders issued by administrative agencies. These orders apply to an industry at large or to uses of a material. The parties subject to them are indicated but not generally named or specified. In this sense the $L$ and $M$ orders are similar to a general rule or regulation issued by an administrative agency. ${ }^{51}$ Formal procedures, in the absence of statutory direction, are not gencrally used by administrative agencies in promulgating rules or regulations. When the WPB issues an $L$ or $M$ order it would seem to be acting in a legislative capacity rather than in a judicial capacity. And the standards of due process applied to administrative orders would seem wholly inapplicable.

Furthermore, ordinary doctrines of law applicable to administrative rule-making may not apply to rules and regulations promulgated under the President's wartime powers. This view has been taken by the Attorney General's Committee on Administrative Procedure in its report: ${ }^{52}$

... the very emergency character of the situations [wars] makes inapplicable the procedures evolved for dealing with the normal regulations promulgated by administrative agencies in the performance of their duties.

$\mathrm{L}$ and $\mathrm{M}$ orders generally are issued only after consultation with interested private groups. This is consistent with the practice of many administrative agencies. ${ }^{53}$ Some statutes require formal notification, hearing and decision based on the hearing record in the promulgation of substantive rules. ${ }^{54}$ In most cases, however, Congress has not seen fit to impose requirements of formal proceedings in the adoption of rules. In the absence of statutory provision, there would seem to be no constitutional question involved in the adoption of rules without formal procedures based on adversary processes. $^{55}$ Of course, there is no statute requiring formal procedures by the WPB.

${ }^{40}$ Federal Communications Comm'n v. Sanders Brothers Radio Station, 309 U. S. 470, 475 (1940).

${ }^{80}$ See Black, Does Due Process of Law Require an Advance Notice and Hearing before a License is Issued under the Agricultural Adjustment Act? (1935) 2 U. OF CHI. L. Rev. 270.

${ }^{82}$ See Fuchs, Procedure in Administrative Rule-Making (1938) 52 Harv. L. Rev. 259, 264-265.

. 20 See Reporr, supra note 40, at ror.

* E.g., Food, Drug \& Cosmetic Act, 52 STAT. ro55 (r938), 21 U. S. C. A. \$371; of. Bituminous Coal Act of 1937, 50 STAT. 73I, 15 U. S. C. A. \$829. See Fuchs, supra note 51, at 278-280; Repont op thiB Attorney Generaz's Comomitien on Administrative Procedure, stipra note 40, at ro8-i1 1 .

${ }^{86}$ Is Saxton Coal Mining Co. v. National Bituminous Coal Co., 96 F. (2d) 517 (App. D. C. 1938), 
The problem of formal procedures in WPB rule-making involves merely matters of fairness and policy. The present consultative procedure would seem to afford interested groups an adequate opportunity to present their views. Formal hearings would seem to be too cumbersome and might cause a breakdown of effective regulation. ${ }^{56}$

Finally, there is the $\mathrm{S}$ order which is a suspension order. The $\mathrm{S}$ order is addressed to a named person who has violated another WPB order. It is generally issued only after the following procedure has taken place. The Compliance Section of WPB sends out investigators to examine and report on the true facts concerning the alleged violation. After investigation the Compliance Section determines whether the facts warrant a charge of violation. If the facts are believed to warrant such a charge, the head of the Compliance Section writes a letter to the alleged violator specifically setting forth the charges of violation. In the letter it is stated that if the alleged violator desires opportunity to present a statement of his views he may do so either by letter or in meeting with representatives of the Compliance Section. If he chooses to meet with representatives of the Compliance Section, a full stenographic record is taken of the meeting. After the alleged violator has been given opportunity to present his views, the Compliance Section considers the full facts as then developed and decides whether a violation has occurred which justifies the issuance of a suspension order. If the Compliance Section decides that an $\mathrm{S}$ order should be issued it recommends such action to the Director of Industry Operations. The Director of Industry Operations then has full charge of the case and makes the final decision as to whether an $S$ order should be issued against the violator. Under this procedure, the alleged violator is given adequate notice of the charges and is afforded an opportunity to present his views.

3. WPB Appeals Procedures. WPB has also worked out appeals procedures to safeguard the interests of those affected by its orders. $L$ and $M$ orders usually have express provisions for appeal. And Priorities Regulation No. I, applicable to all priorities orders and actions, provides generally for appeals from rules, regulations or orders of the Director of Priorities. The appeal is not to a court of law. Rather, it is an appeal to the WPB. The appeal provision is generally in the nature of an exception or exemption from the order involved. Generally, the appeal provision in $L$ and $\mathrm{M}$ orders provides that any person affected by the order who believes that compliance would work "an exceptionable and unreasonable hardship" upon him may apply for relief to the WPB. Some orders provide for appeal not only where the

a question was raised whether notice, hearing and findings of fact were required before the Bituminous Coal Commission adopted price-fixing orders. The question raised, however, was one of statutory construction and not of constitutional issue.

${ }^{\circ}$ Where adversary hearings have been held in rule-making, the resulting procedure has been cumbersome. The record and exhibits underlying a bituminous coal price order totaled over 50,000 pages. Wageorder records under the Fair Labor Standards Act have run to 10,000 pages each. It is noteworthy particularly that the bituminous coal price order was issued more than two years after the procedure leading to it was begun. See Report of the Attorney General's Coammttee on Administrative Procedure, supra note 40 , at 110 . 
applicant believes that an "exceptionable and unreasonable hardship" would be worked upon him but also where compliance "would result in a serious problem of unemployment in the community," or "would disrupt or impair a program of conversion from non-defense work." The procedure is generally for the applicant to address in writing appropriate persons in the WPB setting forth the pertinent facts and the reasons for request for relief. There has been, however, no strict insistence upon formalities for appeal. Informal requests for relief have been treated as fullfledged appeals and acted upon as such. However, practice now in effect calls for the use of appeals forms.

The appeal is usually referred to the administrator of the order involved. The administrator, in turn, may obtain clearances from other divisions of WPB which are interested in the problems raised by the appeal. There are some cases, however, in which clearance is deemed unnecessary and the decision of the administrator governs. Where clearance with other divisions is deemed necessary and is obtained, the appeal is granted and no further appeals procedure is necessary.

Where, however, clearances of other divisions have been sought and not obtained, the appeal is referred to the Deputy Chief of the Bureau of Priorities. The Deputy Chief, in turn, may refer such unresolved appeals to the Curtailment Review Section which considers the issues involved and may hear all interested parties. Investigators may also be sent out to the applicants to gather relevant facts. The Curtailment Review Section thereupon makes recommendations to the Chief or Deputy Chief of the Bureau of Priorities who makes the final decision. There are many cases, however, in which the Chief and Deputy Chief of the Bureau of Priorities have authority to grant appeals in emergency cases without further clearance.

It is noteworthy that Administrative Order No. 5 of the Division of Industry Operations, effective February 23, I942, provides that:

Before granting or denying an appeal, a record shall be prepared by the officer granting or denying the same, showing the reasons for the action taken.

Each appeal therefore is considered carefully and a record is made in each instance. Improvements in appeals procedure are now being worked out.

4. The Role of Industry and Labor Advisory Committees. Although there are no formalized adversary proceedings, persons affected by WPB orders have had, on the whole, ample opportunity to present their views before an order was adopted. Businessmen and labor leaders are in daily communication with representatives of WPB. Every day there are hundreds of conferences with businessmen in which representatives of WPB attempt to find out the problems and views of industry. This participation by private groups serves a dual function: it enables the employees and officers of WPB to obtain valuable opinions and information and it affords a protection to private interests that their points of view have been presented. However, there is no formal requirement for such participation by private groups.

Recently, a more regularized procedure has been set up within the War Production Board for handling industry committees. The OPM issued Regulation No. I2 
on January I4, I942, reorganizing the Bureau of Industry Advisory Committees, which had its origins in June I94I. The Bureau of Industry Advisory Committees serves as a central point of clearance in connection with the formation and operation of industry advisory committees.

It should be noted that industry advisory committees are not for the purpose of seeking consent or agreement by industry to a government proposal but are to advise and suggest upon specific problems presented to them. When meetings are held for the purpose of considering problems affecting an entire industry or a segment thereof or involving questions upon which the views of several segments of the industry are desirable, it is customary to set up advisory committees. A government presiding officer is named for each committee, and it is his task, subject to approval by the Bureau of Industry Advisory Committees, to select a representative group to constitute the advisory committee.

A system of labor advisory committees has also been functioning in OPM and now in the WPB through the Division of Labor, although its organization is not quite as elaborate as that of the Industry Advisory Committees. Joint meetings in which representatives of both labor and industry are present have been called occasionally with favorable results and should be encouraged, where possible.

The industry committees frequently discuss and advise on problems which, if not done under government auspices, might involve violation of the antitrust laws. Therefore, a procedure has been worked out whereby approval of the Attorney General of the United States has been sought for the creation and operation of these Industry Advisory Committees. The Attorney General, in approving such committees, ${ }^{57}$ indicated that he would not approve any specific action taken by the committee but would clear the general character of the contemplated action. The Attorney General also made clear that each industry committee should confine itself to making recommendations to OPM and should not undertake to determine policies for the industry nor compel nor coerce anyone to comply with any request or order made by public authority. Recently, a new arrangement has been worked out whereby it is no longer necessary to obtain the approval of the Attorney General for the formation of each committee. ${ }^{58}$ The Attorney General's approval is now sought only when the proposed activity of a committee makes clearance necessary, that is, when the area of antitrust violation seems involved.

5. The Question of Judicial Review. Opportunity for judicial review is another component of the problem of due process in administrative procedure. There is no

${ }^{67}$ Attorney General Jackson, in a letter dated April 29, 1941, wrote Mr. John Lord O'Brian, General Counsel of OPM, as follows: "Some of these acts if accomplished by private contract or arrangement within an industry and carried on for private advantage would probably constitute violations of the antitrust laws. On the other hand, it is obvious that in the present emergency acts performed by industry under the direction of public authority, and designed to promote public interest and not to achieve private ends, do not constitute violations of the anti-trust laws."

For a more extended quotation from this letter, see Hamilton, Utilization of the Sherman Act and the Price Emergency, infra, at pp. 154-155. Ev.

${ }^{58}$ Exchange of letters between the Attorney General (dated December 22, 1941) and the General Counsel of OPM (dated December 24, I94I). 
express provision for court review of WPB orders. Yet courts have granted a right of review from administrative decisions in the absence of express statutory provision therefor ${ }^{59}$ On the other hand, courts have denied judicial review to some cases because the subject-matter involved was believed to be appropriately within the exclusive province of the administrative or executive agency. ${ }^{80}$ It may be that the activities of the WPB, so closely tied to the executive's war prerogatives, fall into this category. In many cases, the President's determinations have been held subject to little or no judicial review. ${ }^{61}$ Certainly the judgments exercised by the WPB on behalf of the President involve all those matters of public policy which make up the national security and defense-matters hardly fitted to court review.

Thus far, no person has sought to appeal to a court from an adverse WPB order. It is fair to assume that if judicial review of such an order is sought, the United States Circuit Courts of Appeals would be without jurisdiction. ${ }^{62}$ It is possible, however, that a federal district court might assume jurisdiction over the case as an independent suit in equity and thereby review the WPB decision. Judicial review might also result from action by the WPB in seeking court enforcement of its orders. ${ }^{63}$ In any event, however, it has been made clear by the United States Supreme Court that due process is not infringed by the withholding of review of administrative orders by federal appellate courts. ${ }^{64}$

\section{VIII}

There has been no express statutory provision for enforcement of allocation orders as such until the recent enactment of the Second War Powers Act. ${ }^{65}$ Still, until the recent statutory sanctions were made available, there were several possible methods of enforcing the orders. A few of the more important methods have been as follows: Section 35(A) of the United States Criminal Code, which provides generally for criminal penalties for wilful false statements made to a federal government agency, has been and may be useful in apprehending priorities violators who have filed knowingly false information in their applications for priorities. ${ }^{66}$ Similarly, the gen-

${ }^{50}$ E.g., American School of Magnetic Healing v. McAnnulty, x87 U. S. 94 (1902); Ng Fung Ho v. White, 259 U. S. 276 (1932); Shields v. Idaho Central Ry., 305 U. S. I77 (1938); Utah Fuel Co. Y. Bituminous Coal Commission, 306 U. S. 56 (1939).

${ }^{60}$ E.g., Perkins v. Lukens Steel Co., 310 U. S. 113 (1940).

${ }^{01}$ U. S. v. George S. Bush \& Co., 310 U. S. 37 I (1940); U. S. v. Chemical Foundation, Inc., 272 U. S. I (1926); Dakota Central Telephone Co. v. South Dakota, 250 U. S. I63 (r919); Martin v. Mott, 12 Wheat. $x 9$ (U. S. I827); Commercial Cable Co. v. Burleson, 255 Fed. 99 (S. D. N. Y. 1919), rev'd on other grounds, 250 U. S. 360 (1919). But cf. U. S. v. Rodiek, xI7 F. (2d) 588 (C. C. $\Lambda$. 2d, r94I), cert. granted, 62 Sup. Ct. Ior (Oct. 13, 194I), 54 HARv. L. REv. I248.

${ }^{62}$ American Federation of Labor v. N. L. R. B., 308 U. S. 401 (r940).

${ }^{\text {os }}$ See p. 147 , infra.

- American Federation of Labor v. N. L. R. B., 308 U. S. at 412.

${ }^{05}$ Pub. L. No. 507, supra note 22. For a general discussion of the enforcement powers, see Note, American Economic Mobilization (1942) 55 Harv. L. Rev. 466-467.

${ }^{\circ 8} 48$ STAT. 996 (1934), as amended, 52 STAT. 197 (1938), r8 U. S. C. A. $\$ 80$ (Supp. r939). The penalties provided for $\$ 10,000$ fine or Io years imprisonment, or both.

This method of enforcement was resorted to recently in the U. S. District Court for the Southern District of Indiana. An indictment was brought under $\$ \$ 35(\mathrm{~A})$ and 37 of the U. S. Criminal Code against an Indiana tire dealer for alleged violation of OPA's tire rationing regulations. The indictment charged that offeers of the tire dealer knowingly filed with the State Defense Council a false inventory of 
eral provisions of Section 37 of the Criminal Code against conspiracies to commit any offense against the United States possibly may be invoked to prosecute persons who conspire to violate priority or allocation orders. ${ }^{67}$ However, to date the most powerful enforcement device has been the administrative technique of suspending all allocation of raw materials to violators of priority or allocation orders or of withdrawing priority assistance from such violators. ${ }^{68}$ Moreover, a violator may be placed on the War Department's blacklist, thereby making him ineligible to receive new government contracts until he has recanted. Although the court injunction has not yet been used extensively, ${ }^{69}$ it would seem that the Government might invoke the aid of equity jurisdiction to enforce the priority and allocation program that Congress apparently intended to be mandatory and enforceable. ${ }^{70}$ Finally, public announcement of violations remains as a possible method of enforcement. Criminal sanctions for wilful violation of any rule, regulation or order issued under Section 2(a) of the Priorities Act, as amended, have been made available to the War Production Board by the recent enactment of the Second War Powers Act. ${ }^{71}$ Title III of that Act provides penalties up to $\$ 10,000$ fine or one year's imprisonment, or both, for wilful performance of any act prohibited, or wilful failure to perform any act required by Section 2(a) of the Priorities Act, as amended, or any rule, regulation, or order issued thereunder. These punitive provisions of the Second War Powers Act should help make the priority and allocation programs fully effective in the prosecution of the war effort.

In this connection, it might be added that the problem has arisen whether persons who obey the priority and allocation orders and thereby default on other private contracts, render themselves liable on these contracts. The -Vinson Act of May $3^{\mathrm{r}}$,

tires and tubes in stock and knowingly concealed and covered up their alleged evasion of the rationing regulations by destroying inventory records, storing new tires and tubes belonging to the company in their homes, making surreptitious deliveries of new tires and tubes from these stores, and making false invoices describing sales of new tires and tubes as sales of used tires and tubes. U. S. v. LaSalle Motor Sales Corp., OPA Release No. PM 2498, Feb. 15 , I942.

${ }^{o 7}$ REv. Stat. $\$ 5440$ ( 1875 ), as amended, I8 U. S. C. $\$ 88$. The penalties provided are $\$$ ro,000 fine or 2 years imprisonment, or both.

${ }^{68}$ See, e.g., WPB Suspension Order Nos. S-8, S-9, S-r2, Feb. ro, r924. 7 FED. REG. 945, 946 (194I).

${ }^{\circ}$ In the first action of its kind yet taken, an injunction was sought against the Chicago Alloy Products Company from a U. S. District Court in Chicago to restrain it from interfering with agents of the WPB in enforcing a WPB order directing the company to afford access to its premises for inspection of its inventories, books and records. The court issued a permanent injunction requiring the company to permit audit and inspection by government agents and to refrain from disposing of its stock of metals until the audit had been made. The company was also perpetually enjoined from violating any regulations or orders issued by the WPB. WPB Release No. 218, Feb. 13, x942; WPB Release No. 468, March 7, 1942.

Recently the Price Administrator applied to a U. S. District Court in Norfolk, Virginia, requesting an injunction against the transfer of tires and tubes contrary to rationing regulations issued by OPA. The defendants challenged the validity of the rationing regulations. The court upheld their validity and issued a permanent injunction restraining delivery of the tires and tubes without OPA authorization. Henderson v. Smith-Douglass Company, Inc., et al., OPA Release No. PM 2498, Feb. 15, r942; OPA Release No. PM 2640, March 6, 1942. Since OPA rationing power is delegated to it by the WPB, its authority would seem to be bottomed on the same structure as that which sustains the priority and allocation orders of WPB.

${ }^{70}$ See H. R. Rep. No. 460 , 77th Cong., Ist Sess. (I94I) 2-5.

${ }^{71}$ Pub. L. No. 507, supra note 22. 
I94I provided immunity for such defaults. Recently, the Second War Powers Act has broadened this immunity so that it now reads as follows:

No person shall be held liable for damages or penalties for any default under any contract or order which shall result directly or indirectly from compliance with this subsection (a) [Priorities Act, $\$ 2(\mathrm{a})$, as amended] or any rule, regulation, or order issued thereunder, notwithstanding that any such rule, regulation, or order shall thereafter be declared by judicial or other competent authority to be invalid.

When Congress gave the President power to allocate materials where shortages appeared, it necessarily must have contemplated that some private contract orders would be displaced. Otherwise, the priority and allocation system would be meaningless. Obviously, Congress did not intend to render those persons liable for default on private contracts for doing their part in the interest of national defense. ${ }^{22}$ Still there seems to be some doubt whether this statutory provision is applicable to all situations. ${ }^{73}$ Yet it is to be hoped that the immunity from civil liability for breach of private contract afforded by the Vinson and Second War Powers Acts will not be interpreted narrowly by the courts in the light of technical doctrines of impossibility, illegality, and frustration of performance. The "no-damage" provision of these Acts was intended to facilitate participation by persons in war production and should be interpreted in that light.

\section{IX}

The allocation program is rapidly becoming more comprehensive as the country gears itself for full-time war. When we first embarked upon an armament program, the problems were different. At the start, when the program was small and especially when there were unemployed resources, it was enough that the military procurement agency established to procure necessary military equipment was given the power: (I) to require the acceptance of orders which it placed; and (2) to insure that such orders were given priority as to time of fulfilment. It is logical, therefore, that the first orders which came into prominence were $\mathrm{P}$ orders or Priority Orders, giving preference to military production. As our armament program developed, however, shortages became increasingly acute; hence it was not enough to give military production priority as to time but it became necessary to control the amount going into various uses by means of $L$ orders. As shortages first became acute among raw materials, especially metals, allocation of the amounts available between different uses was first undertaken, by means of $M$ orders, for such materials.

The final stage, which we have not yet fully reached, is one in which shortages are no longer confined to certain scarce materials but apply to materials in general, including power, fuel, transportation and other productive and service facilities, and manpower. When this final stage is reached, allocation of all our productive resources may become necessary.

\footnotetext{
${ }^{72}$ See Note, American Economic Mobilization (1942) 55 HARv. L. REv. 474-476.

${ }^{73}$ See Brown, The Effect of Conscription of Industry on Contracts for the Sale of Goods (1942) 90 U. of PA. L. Rev. 533 .
} 
Just as the situation in regard to military production has changed with the expansion of such production, so also has the work of the Division of Civilian Supply. During the Fall of I94x, the major concern of the Division was aiding in the curtailment of unessential civilian uses of scarce materials. During last Fall, most of the materials needed for civilian production were available, so that a relatively equitable distribution could be obtained simply by limiting the comparatively unessential uses of materials. But just as it has become increasingly necessary to allocate scarce materials among various military uses, so also has the work of the Division been shifting, as scarcity increases. From cutting off less essential civilian uses of materials the Division is progressing to allocation of the supplies available for civilian use and to insuring the availability of supplies for minimum essential civilian needs. In short, as we shift from a military program taking a small part of our productive effort to one taking the major share, the work of the Division will shift from freeing materials for military requirements by cutting off relatively unessential civilian production to procuring, much as military materials are procured, those civilian supplies which are necessary if the war effort is not to be impeded by inadequacies in the civilian standard of living. In large measure, therefore, the aims of the Division of Civilian Supply are to guard war production against dissipation by excessive civilian production; to measure the essential needs of the civilian population and to stimulate and secure adequate production to meet these needs; and to protect the civilian population against undue impairment of its standard of living. 